\title{
Adoption and Pricing: The Underestimated Elements of a Realistic IPTV Business Case
}

\author{
Koen Casier, Ean Lanoo, Jan Van Ooteghem, Sofie Verbrugge, Didier Cole, Mario pickavet, \\ and Plez okmester
}

\begin{abstract}
The adoption of YPTV increases competition for telecom aperators. Especially video on demand and the move to KOTV push the bandwidh requiements to the limits. It is very challenging for an operator to construct a successful and sustainable introduction of IPTV over the existing infrastructure. This article gives an overview of a typical business case followed by a detailed discussion of the adoption and evalua sion of the outcome. The results of this article indicate the importance of a correct choice of adoption model and related parameters. It illuskates how different pTV-specific effects on adoption (i.e., competition and analog switchoti) might bave a considerable impact on the outcome. After atoption, the artide shows how the oukcone of the business case can be used within prieng dewsions by seting sustamable and competive bomwases on the tarite Finaly, as pricing will also have an important imaret on

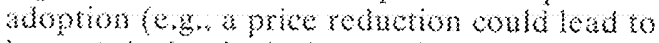

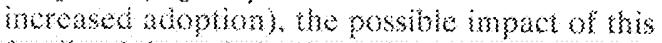

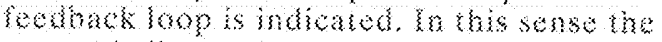

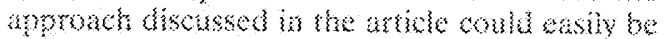

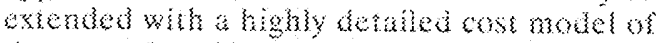

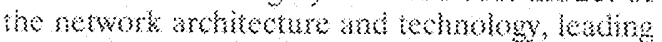

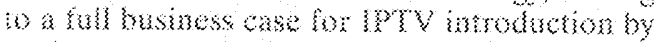
a kecom mosator.
\end{abstract}

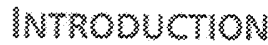

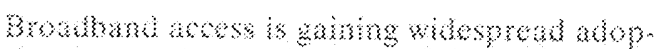

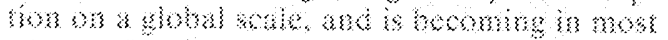

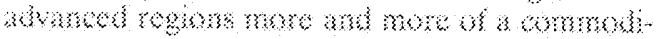

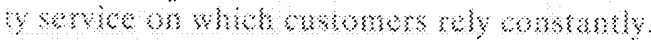

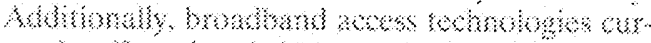

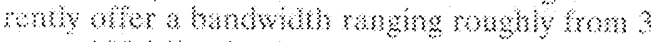

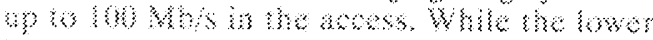

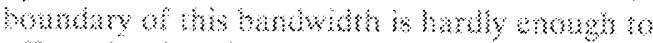

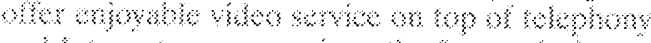

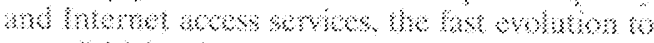

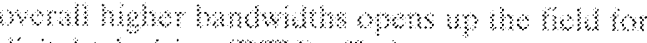

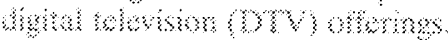

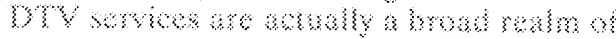

diferen services (e.g., video on demand [Von], broadcast. network personal video recorder [NYVR]) and technical platforms (digital video broadcasting terrestral (OV 3 - Ty or satellite [DVB-S], PPTV, over the-top video \{e.g. YouTube], etc.). We focus on DTV as offered by fixed broadband access networks. In the remainder of the article we refer to this as IPTV.

At the customer premises a setup box is attached to the existing video infrastructure, and it decodes the digital signal into the required television signal. Thus, from a customer point of view there is fittle change, and the meaningfu? differences between altemative IPTV offerings are functionality, quality, and tariff.

From an operator poin of vew, the diferent possible services and technical platroms will bave an important impact on traffic and thus on

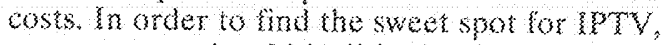
an operator should build a business case in which hate costs, caused by functionalicy and qualiy, and revenues, ganed from cuskomer

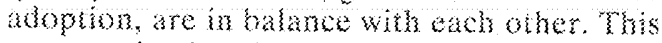
means solecting the righe set of conditions for

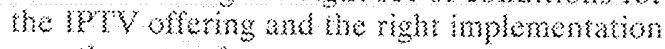
wex the nekwork.

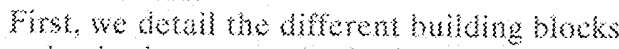

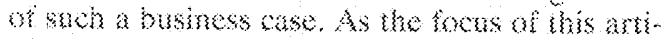

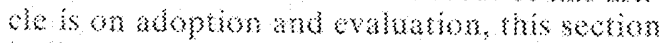

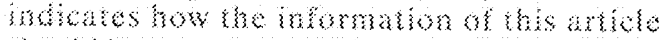

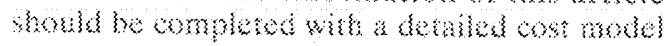
to conktures a thl humbes cane.

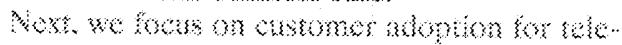

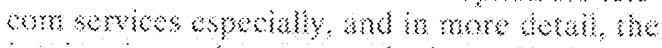

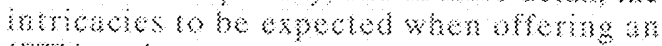
\{3

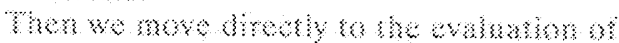

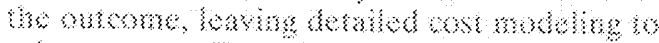

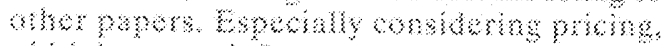

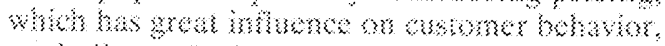

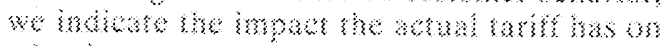

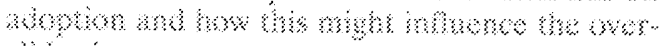
al ॠrkes

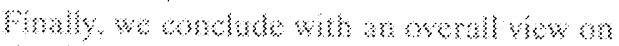

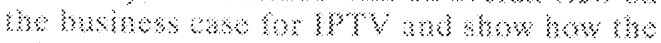

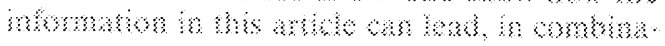




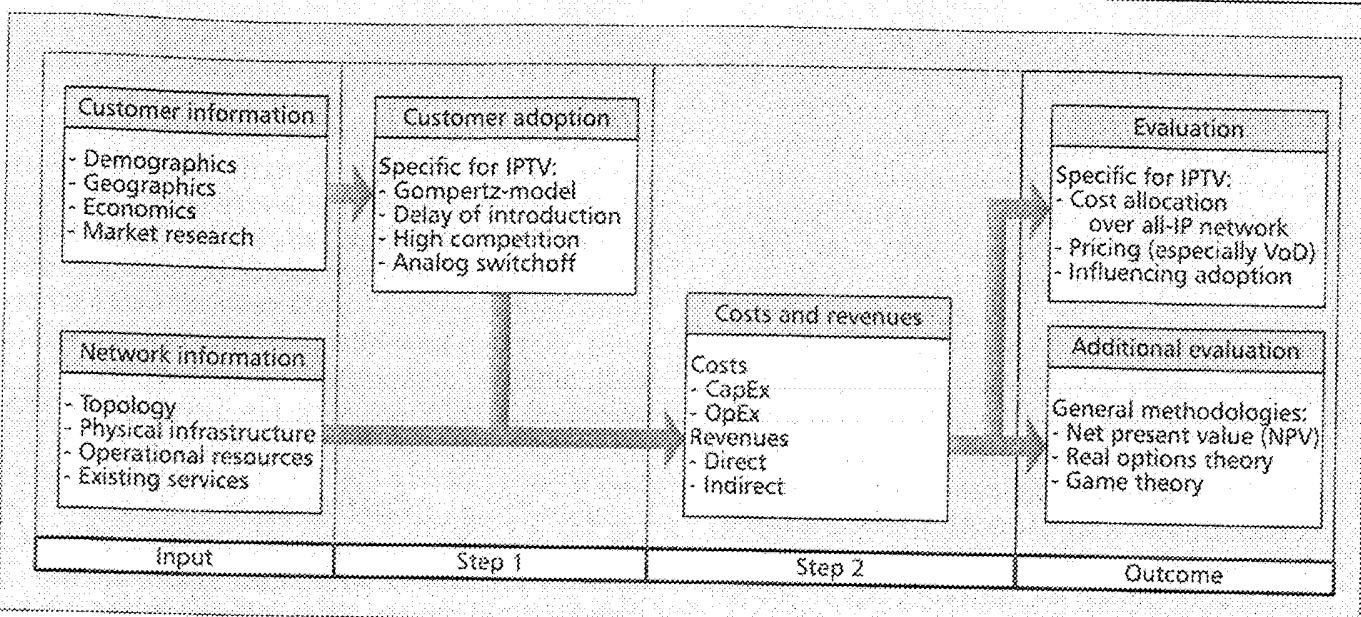

Fionse Mathodology for building a business case.

Lion with lechnological modeling of YPTV, to a clearer view of profinability and arifit boundarios for a telecom operator when if plans to introduce an IETV service.

\section{BUSINESS CASE OVERVIEW}

A business case aids managers in making deliberate decisions on when and how to deploy a new service or produce a new product. For the introduction of XPTV, the business case should provide rationales for making decisions on when to deploy which type of IPTV service. In this sense the business case aggregates all information on expected expenses and revenues gained from the rollout of such a service. Figure 3 gives an overview of the methodology used in this article for buiding a business case.

In the preliminary step of the business case, we gather all inpu infornation of importance to the projecs. This includes customer behavion, equipment pros, extisng intrastructure, and so on.

Based on this inpul we calculate, in the first step, custoner adoption. This incomation will te erbetal to the knak ouwone, and a thorough

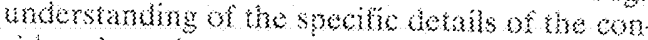

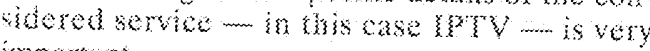
moreman.

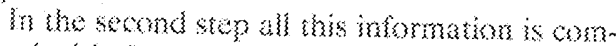

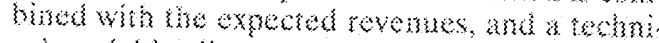

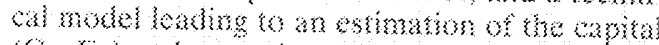

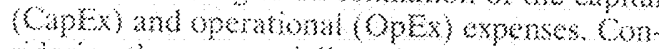

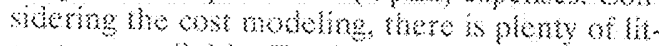

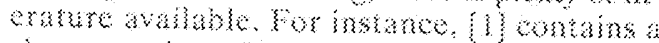

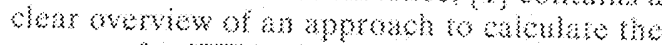

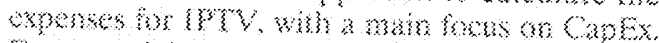

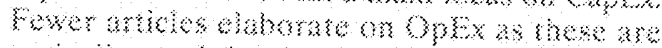

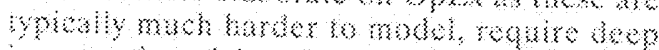

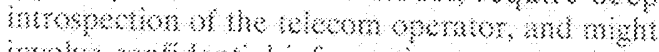

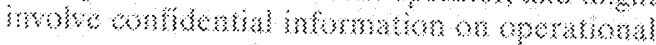

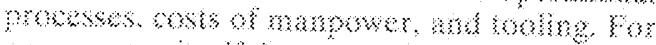

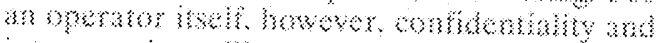

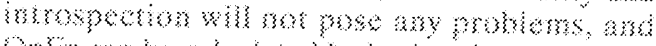

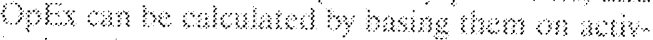

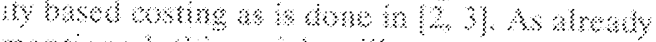

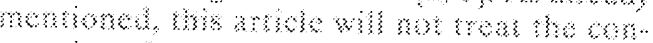

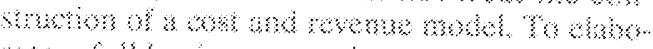

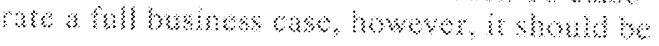

completed with detalled information about both costs and revenues.

The final steg of the business case rekntes the different cash flows generated by the revenues and expenses for deploying lpry over the network. in order to evaluate the project, we can calculate important economical indicators, like return on investment (ROI), net presene value (NPV), or payback period. Furthermore, in a valid business case we expect all expenses to be at least covered by all revenues over the given period of the project. Bottom prices for the service can then be calculated from the expected costs and expenses.

Kt should be noted that the proposed business case focuses on adoption and pricing, and does not contain all possibie infricacies of the param. eters of such problen, but only a subset of the inferactions between the different elements. Considering the high number of technological, strategic, and business parameters, constructing a fuly dewiled nodel is a very complex task.

\section{ADOPTON OF IPTV}

Whe purpose of a goobl adoption model ts to

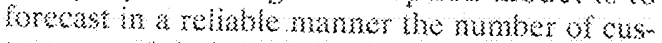

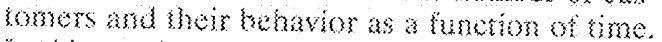

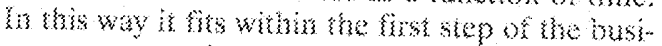
ness case weriew as promser bethe Dherem

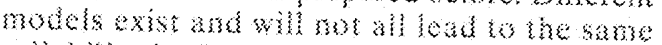

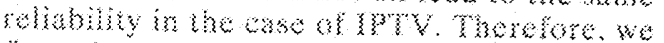

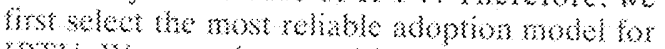

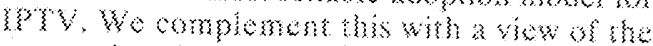

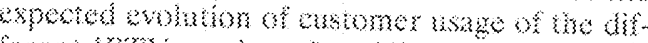

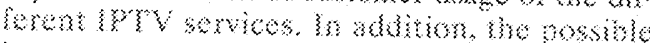

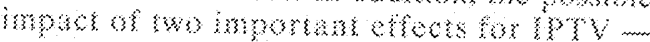

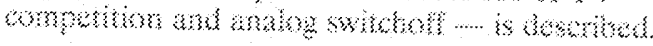

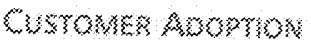

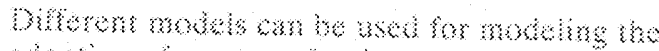

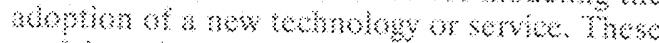

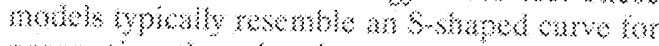

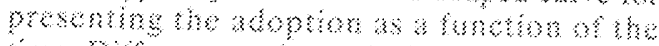

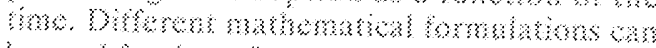

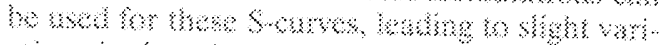

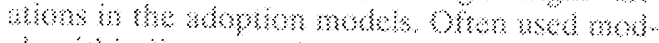

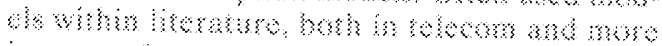

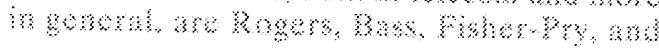

The purpose of a jocol soloption model 5 to rorecast in a reliable namor the rumber of customers and theit bermswor 33 : function of time in this way 10 fits with the hist stap of the business case overvisw: 


\begin{tabular}{|c|}
\hline 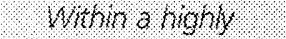 \\
\hline comperitrva morrat. \\
\hline as is thes case ior \\
\hline belscorn services orid \\
\hline 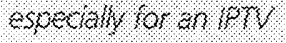 \\
\hline senver whers. \\
\hline 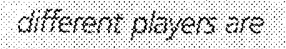 \\
\hline 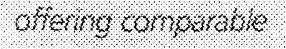 \\
\hline 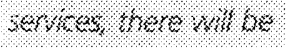 \\
\hline ( \\
\hline 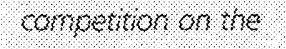 \\
\hline $0.0,0,070.1 \%$ \\
\hline
\end{tabular}

Gomperz, Roughly speaking, information used for properly estmating the parameter values of these nolets ean be gained fron wo sources:

1) Fitung of the mathematical adoption modes to existring âoption data avaluble. This requires anficient data to be avalable and thus rogkes an existing customer base. for IFY this might not atwas be the case

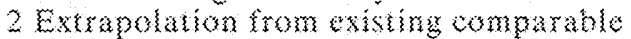

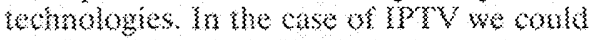
make an extrapolation based on letecom

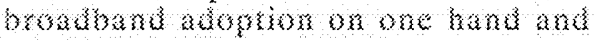

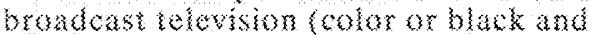

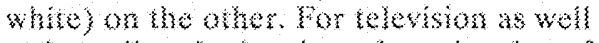
as brondband adoption, there is a hot of information anatidabe.

When considering he dixerent mathematica formalatons for modeling the adoption, it is clear that not an fittings will be as close to the actual data. However, the reliabiling of the fore castec aubotion is of buge importance. Intrinsically lpry is valk on both broadband and television. As broadband access (and its adop

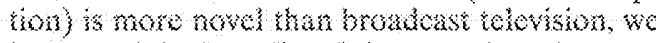
have use the broatband data to select the most reliable model for forecasting IPTV adoption. To make a well considered selection, we have fitred the adoption models to existing data in two diferent ways. First, we have investigated the relability of the models in the range of the data. Therefore, we have fitted each model to all avalable data and have calculated the difference between he fited and exact data. The more reliable a model, the more closely it will follow the exach data. Second, we have investigated the reliability of the model for forecasts beyond existing data. Therefore, we have fitted the model to the first available data points (e.g., the first 50 pereent and then calculated the differ ence beween the fitted (forecast) values and the exact values tor the remaining data points. The more relable a model, the less difference there will he between the forecast and exact a ata for this remaining part.

Difterent thungs made on existing telecom

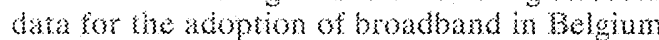
show that bath the existing ands forecast a a a are mone refably modeled asing a compertz adop. hom nombl.

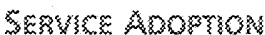

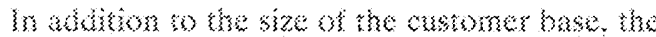

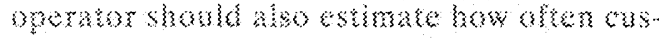

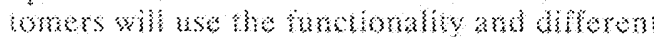

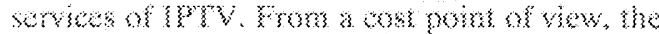

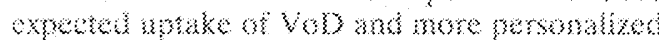

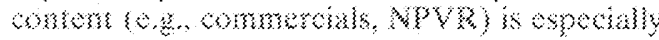

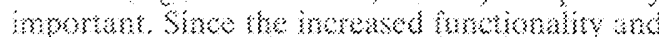

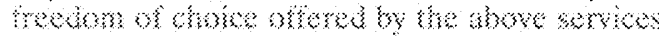

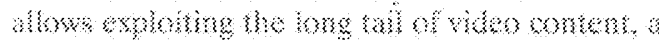

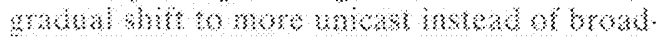

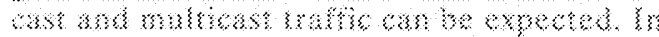

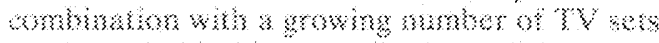

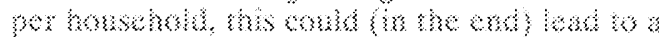

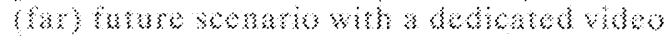

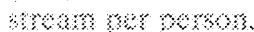

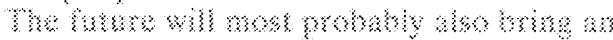

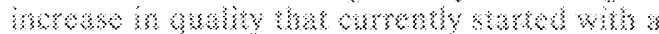

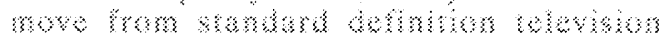

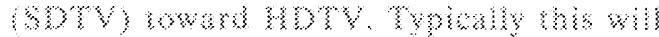

increase the bandwidra required per strean. somewhat tempered by continuous advances in vileo codecs.

Aithough the imoact of both the move to per

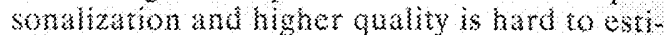
mate, an increase in both is very likely, and theis

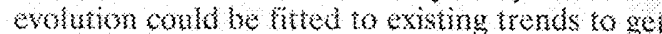

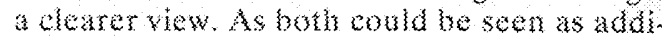

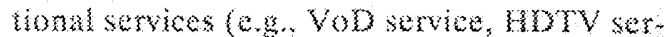

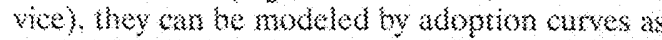

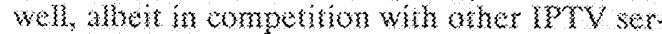

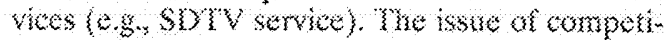
bion is rackled bolow.

\section{Comprarnon}

Witum a highly conzentive market, as is the case tor telecon services and especially for an 3FV service where diferent players (e.g. con kent poviders, felecom operators of fer compan sable services, comperition will have a direct impact on atoption. Also, the competition with othar OTV okerings (not over bxed broabluand access) such as DVB-T or DVB-S will ba very importan tor the sucoeso of 1 m?

Game theory is a very complete approach to moleling the effect of competition. It involves the construction of a detaled business model of all players and their possible actions. Additionally, all the different business cases should interact with each other to reflect the impact of the actions of all players. It thus involves a los of work on the integrated models and a lot of inpus data that might not be avallable.

On the other hand, it might suffice to use a combination of an adoption and substitution model as proposed by Norton and Bass [4]. In such a model different generations of the same or comparable technology or service le.g., SDTV vs. HOTV, or more generally a notion of the perceived quality) will interact with each other and with the initial customer adopton. A generation with superior technology, quality, or ser viee will take oyer the adopton of the other generations. Ir i farby staightorwark to extend the bes fitung - here Gompertz - adoption

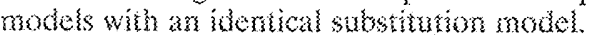

\section{AnAzos SNMrror}

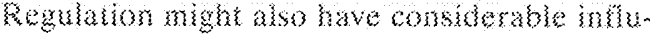

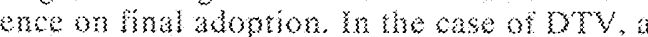

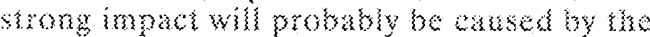

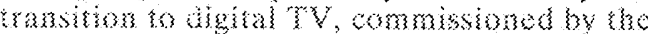

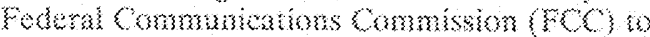

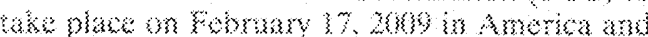

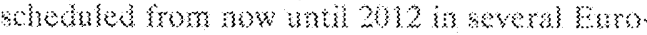
perm commuss.

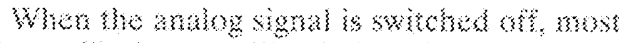

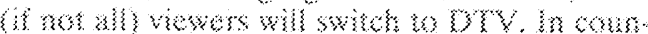

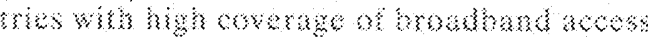

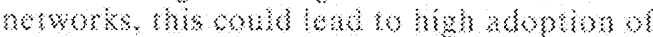

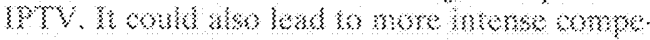

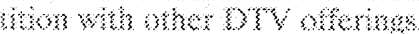

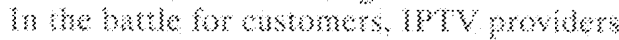

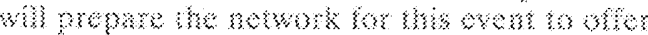

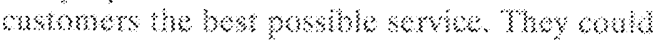

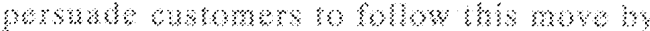

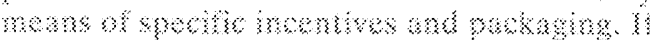

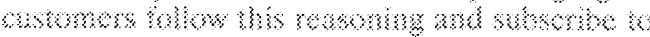

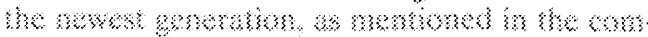

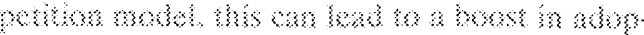


thon of the generation. Given the incentwe of this nevest generaturn, he moact of aralog switchoff can the splu bewaen the diferem services according yo customex willingness to pay and preferences

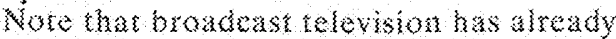

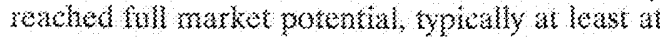

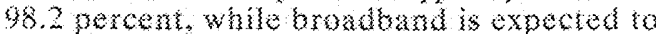

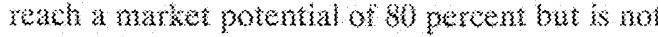
yet at this woinu in most combutes.

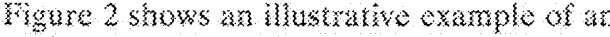

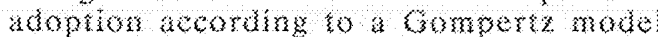

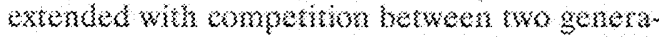

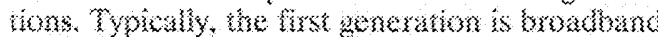

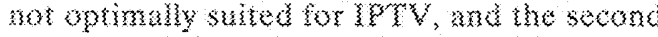

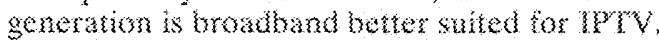

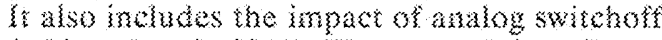

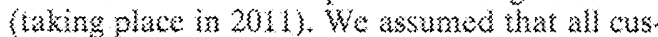
tomers choose ry custoners choose the newest gereration. "This means we assumed thas the total atoption of

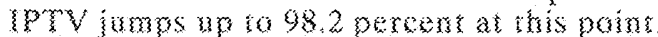
This could, for instance, be the case in a comnry like belghm whin a high penetration of hived access nerworks.

\section{WHAT TO DO WHW THE COST}

HeV requires hage bandwidhs over the network. It will most probabiy require upgrades of the nework equipment. The size of the upgrades will depend on customer base and their usage pattern (a.g. VoD va. broadcasi) and migh affect access and backhaul in a diferem manner. In order to find a viable business case, the oper ator has to cover at leass all costs by the revenues. This means the operator can calculate a minimal requirea average return per user (ARPU). These calculations are part of the last step in the business case overview as proposed betore (Fig. 1).

We iust focus on how imoranan it is no isor late the cos incured bo Wh services from the total cost of all services. Next we investignte the

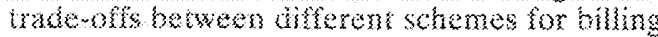

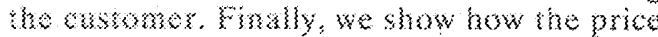

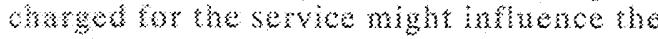

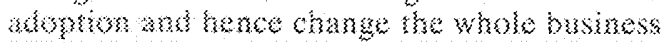
rak

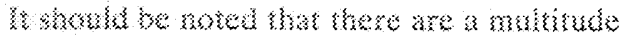

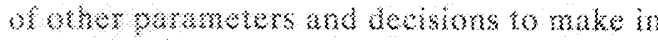

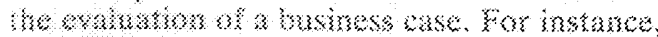

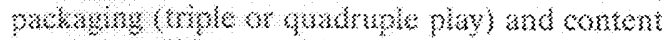

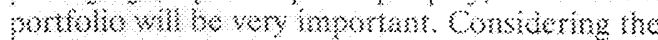

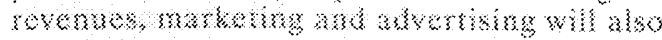

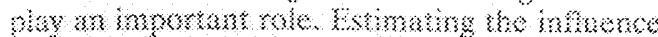

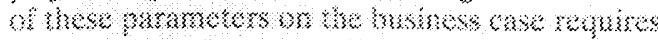

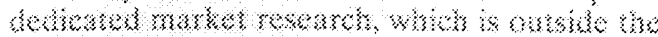

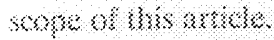

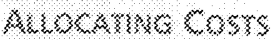

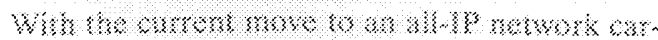

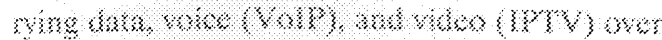

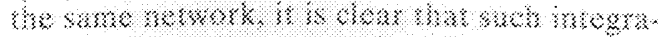

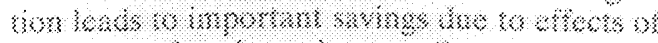

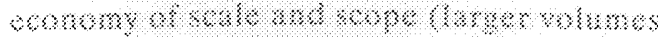
aho\% एu

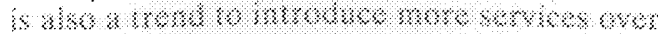

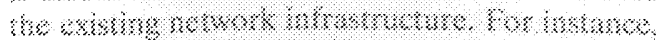

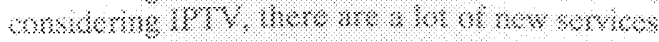

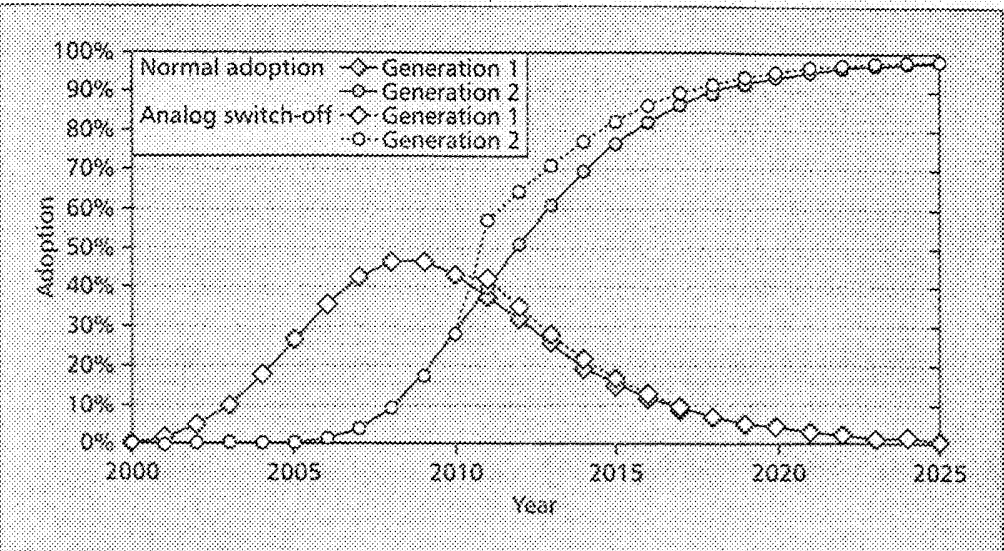

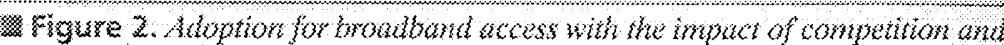
whalog swimbloff.

that can be deployed, such as VoD, NPVR, tece banking, and video telephony.

With his increasing number of services an maning over the same nework intrastucture, if becomes very difficult to estimate for each ser vice how in will contribute to the overall networix infrastruchure cost. A clear indication of the costs confributed by each service is very homortant to get an idea of the profitability of each service. Additionally, when detemining the bot tom tariff to chatge for a service (either at introduction or at a later point in time), the cost will be the main input. Different allocation schemes exist for spliting the total cost of a network operator between the different services it pro vides. More information on the different types of costs and the rationale behind thex allocation can be found in $[5,6]$.

Figure 3 shows the difference between the botrom prices calculated according to dixterent allocation schemes. The allocation scherne used in the ealentations of the costs will have an importan haluence on the botrom proe calcu lated for the service. Aduitionally, the figure shows the results for lour different planning

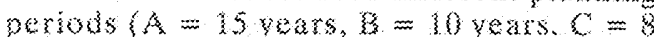

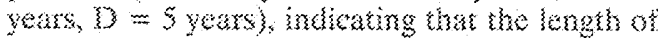

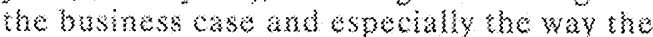

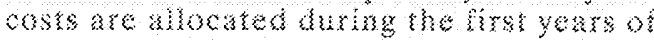

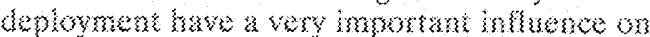

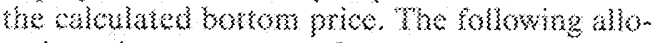

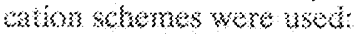

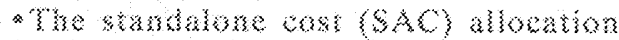

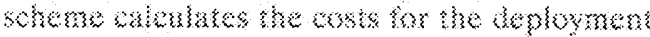

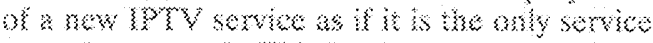

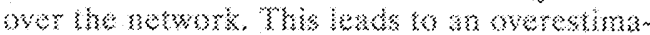

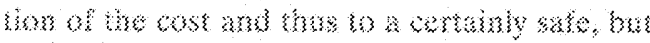

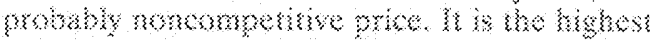

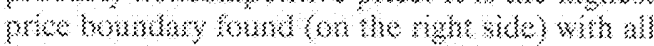

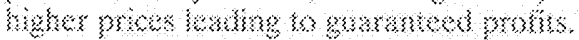

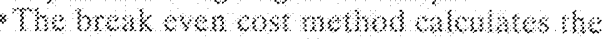

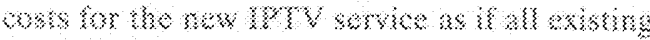

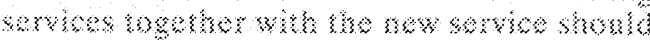

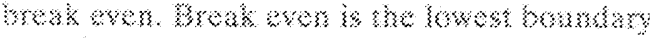

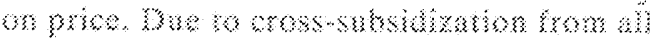

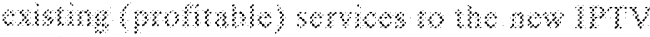

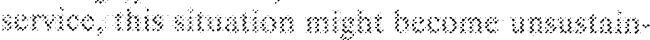

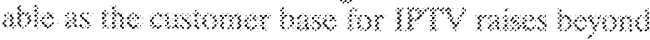

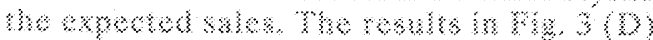

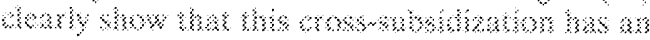




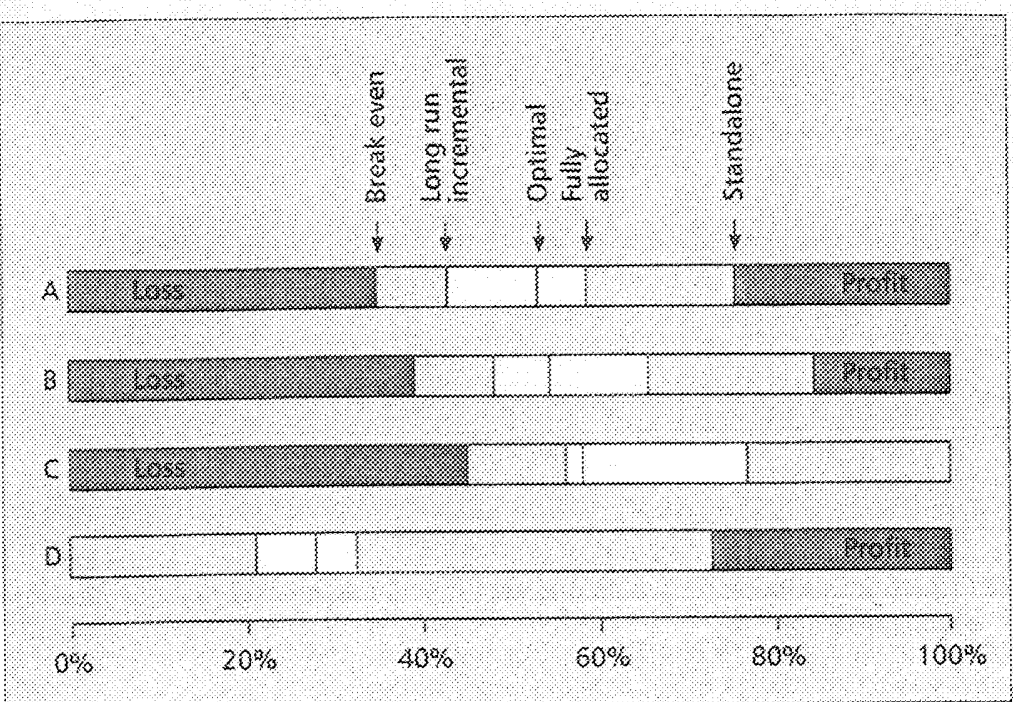

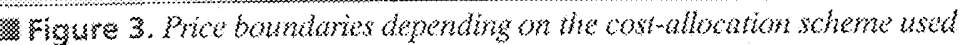
(nommilined to max. SAC (C)).

importane impact in the first years of the project.

- Fully allocated cost (FAC) is the allocation scheme in which all costs are split according to the actun resourees being used. Such fully allo cated cost calculation is based on an allocation key, such as bandwidh overall or peak usage. calculated in advance for all services. FAC resurs in both a competitive and sustainable price towards the customer, on condicion that a correct allocation key is used. Different functionalities and requirements of data transport (e.g. bandwidth, quality of service, relation to peak bandwidn) could be taken into accounc.(e.g., VoD will require much higher [dedicated bandwidh than broadcasted video and shouh contribute a larger cost, unless if some technolugies are used to reduce this bandwidith as the weak noment).

- Long run incremental cost (LarC) scherne alsocates only the incremental cost for the

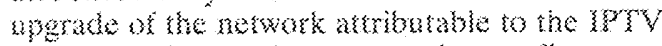

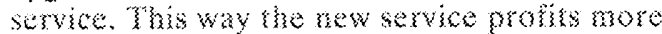
trom economy of wabe for its ouse whick rexuls in a kower boundury.

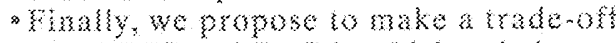
\{etwes a

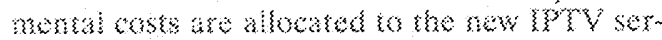

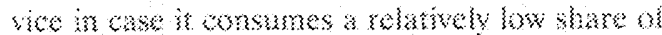

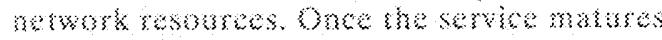

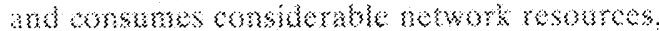

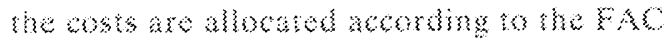
shame.

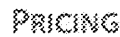

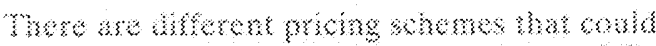

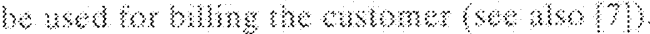

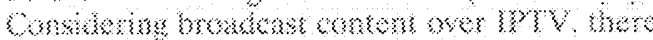

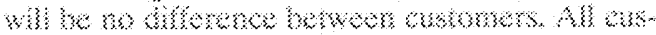

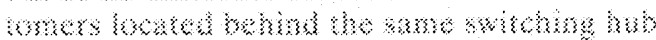

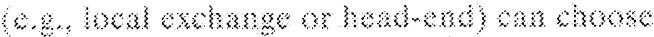

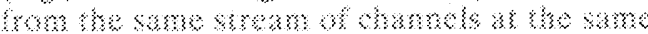
has and are chered he wame wheher they

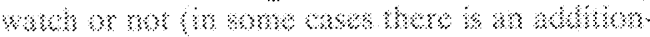

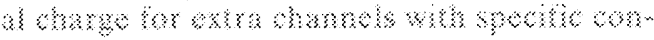
«.s?.
When VoW is considered, the siutation is diflerent Providng VoO to maxy customers requires large anomits of bandwidth and conkd lead to congeston. In such a situation it makes

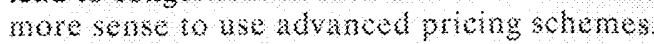
The reyenue ofect of asing a speitc pricing

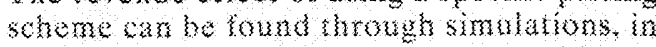
which the knith the customer is charged is calculated acombina to the spectic pricing soleme

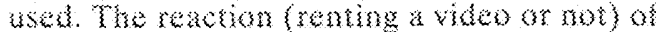

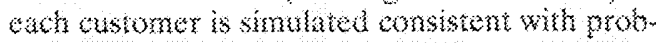

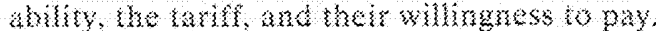

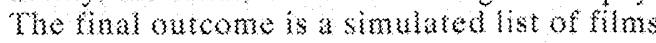

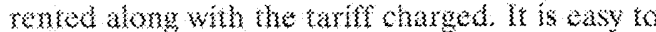
calculate he revenues or the differen pricing schenes.

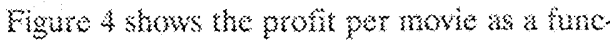
tron of the tandxc congestion in the network for the bollowing oricing soluenes:

- Flat rate or contene-based - Charoing a fixed tarifin per mowic, possibly depending on the movic's content, qualiy, or kergth.

- Time-olndaynbaser - Charging a harif depending on the time of day the wavid is rented. A hisher saxily is charged for nowies rented during peak periobs.

- Congeshon-based - The rarizcharged depends on the level of congestion in the nework. In our implementation the tariff is linearly increased once more than 70 percent of the bandwidth is consumed at peak.

- Auction -based - The tarife charged is deduced from a (agenk-based) Vickrey auction. In this the customers indicate the price they are willing to pay, from which a market clearing price is deduced. This market clearing price will be the tariff charged to all customers who bid at least this price.

Traflic used tor the simulation has peaks between 18 and $22 \mathrm{~h}$. Al 0 peren tratfic con isestion, the highest peak consumes all avalahb bandwidth without any blocking. The simation below on pereat traftic condestion is left out of the rigure as the abvanced proing schemes bad to protirs per movie that are lower than those of

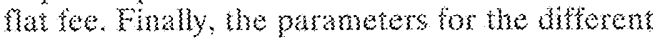

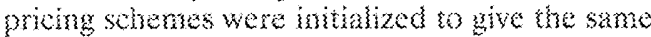

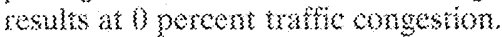

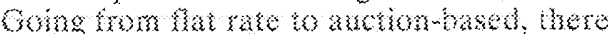

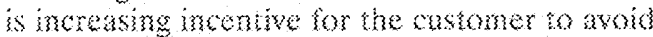

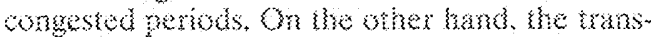

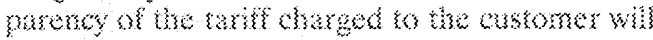

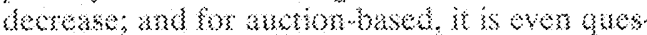

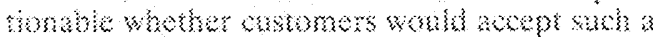

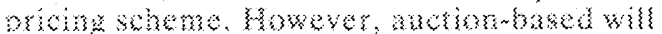

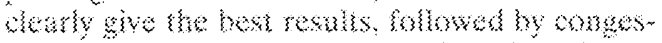

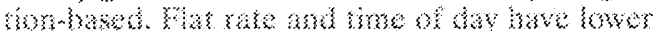

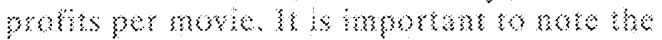

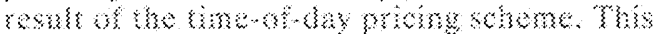

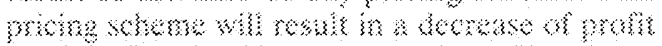

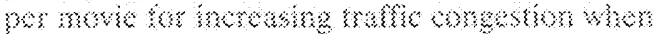

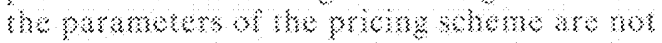

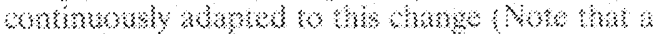

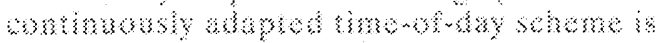

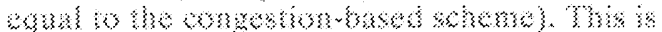

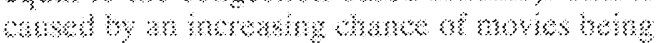

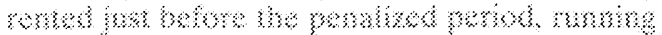

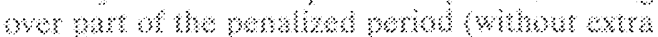

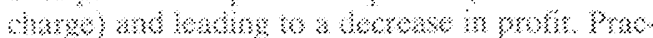

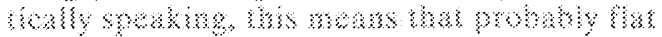


rate is the most obvious obolee as it is mos namspaxent and has a more or less constan protit ger mowe. Congestom-based and sepecial

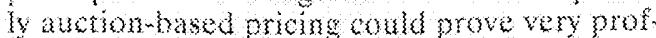
table in those rase where considerable

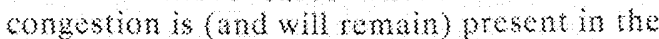
nework. M strong adomitom of Vob is expected and network bandwidun so not (or wanon) be

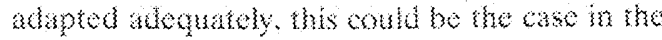
rance.

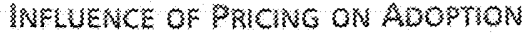

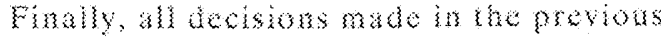

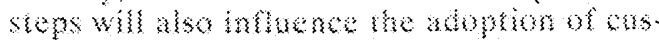
comers. The forecast of cuspomer aboption

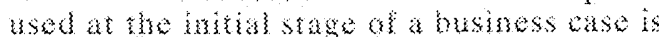

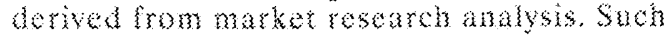

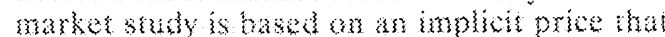
is expocied to be both a a a inable considering

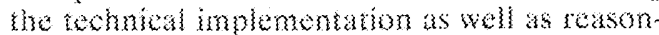
able tor customers, la fust calculations prove that this pres is not atuande and a (sighty) higher price should be set for gary service, probably rewer customers will stoserbe to the service. In other words, charging a higher prico than initally anticioated will lead to a rebue tion of customer adoption, and might lead to a smaller upgrade of the network initrastruck and thas to lower Capex in the first years of deployment.

In an IPT V environment there might be considerable investments at the start of deployment for instaling content servers, acquiring the right content, and uggrading the bandwidh in the access network where necessary. "lwus, for IPTV the loss of revenues caused by the reduction of the customer base could impact the business case more substantally than the reduction (post poming) of Cayex. In such a case this leads to a further increase in price.

Results from such an iterative calculation have been indicated in [0] and show that, beponding on the expected inpact of the proschange on the customer abopton model, either a sligh relaxarion or reinforeduen ean be

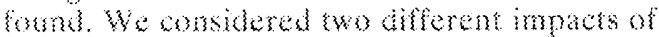
the tartit on the abopton model hn a hest case

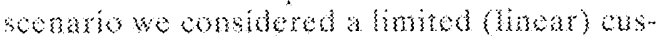

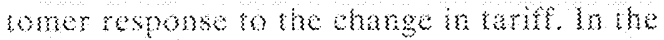

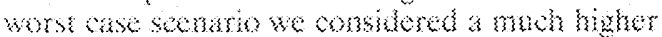

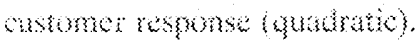

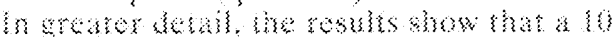

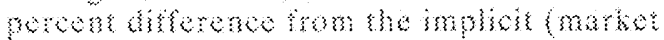

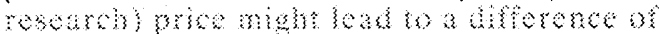

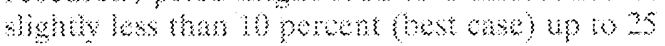

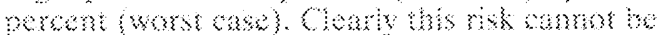

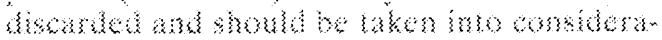
ins.

\section{conculson}

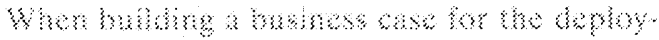

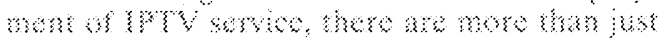

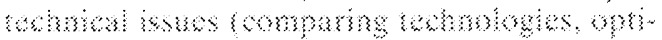

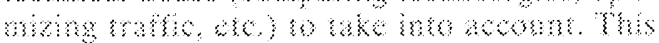

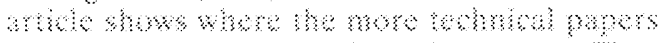

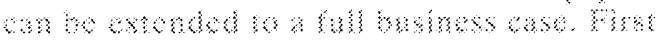

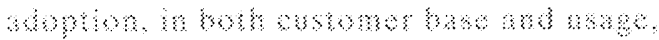

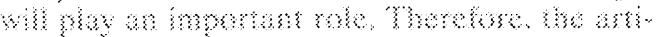

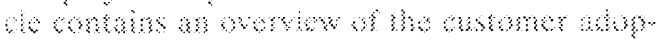

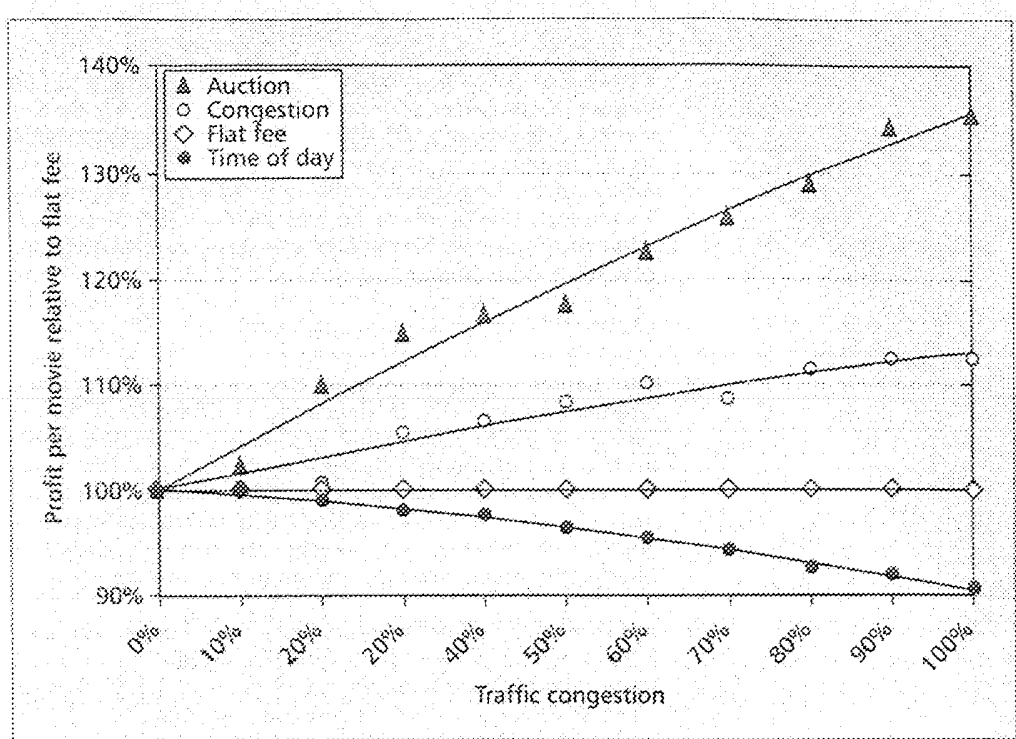

wigure 4. Profi per movie as thaffic congestion increases.

Fion models and diferent parameters that influence this adoption for $19 \mathrm{PV}$. The most important parameters here are the clocice of adoption model (compertz is tound to be the best), the extension toward nodeling competition, and the effect of analog switchot, See ond, the evaluation of costs and especially pricing will have an important influence on the business case. By allocating costs farly to KWTV and all other services, more competitive yet still sustainable lower boundaries on pricing ean be calculated. The second pricing parameter is the pricing scheme to use, for which lat rate pricing is optimal in a low congestion situation and congestion-or auctionbased are promising for situations with higher congestion in the network. Finally, as pricing whll also infuence customer adoption, the ous come of the husiness case might change its inputs. This effect should not be neglected as it might lead bo imporant diberences and con gled risks of oppomanizies.

\section{REFERENCS}

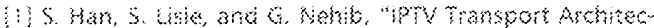

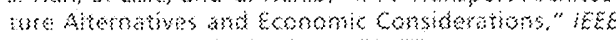

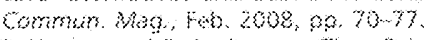

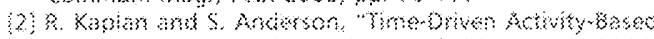

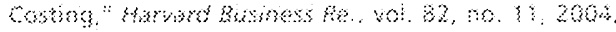
n. $20 \%$

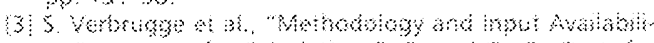

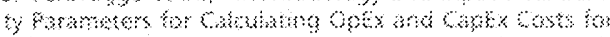

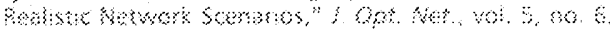

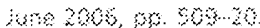

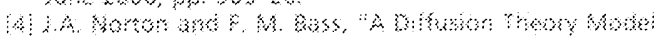

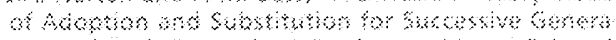

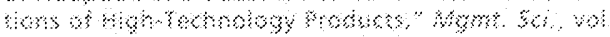

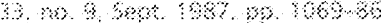

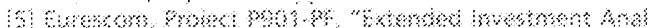

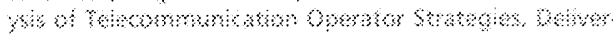

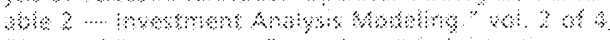

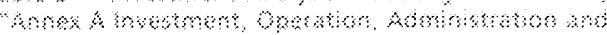

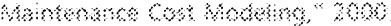

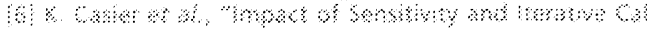

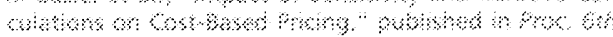

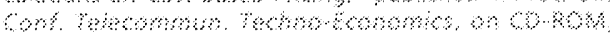

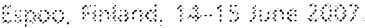

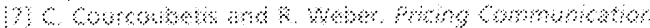

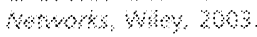




\section{BIOGRAPHIES}

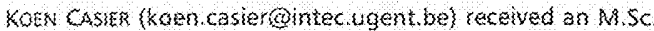
begre in computer science engineerng trom chant uni versty, belgim, in 2003 He joned the bri-groug of the

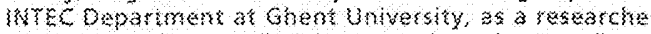

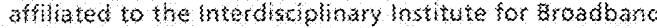

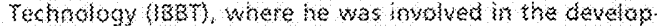

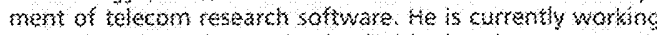
haward a ph.D. begree in the tiekd of kamo-aconomic

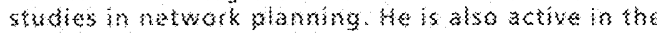

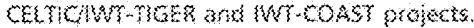

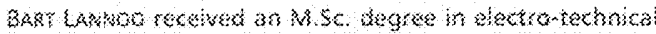

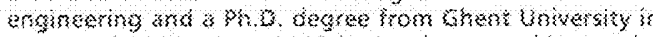
2002 and 2002 . Since 2002 he has beso wotking at the

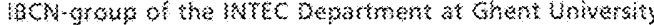

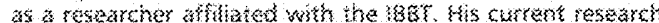

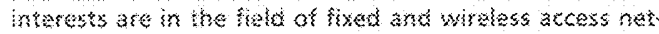
works, nchuding tachncal and technoreconomic studies on

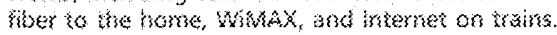

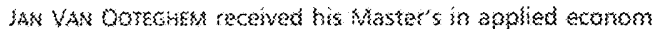
ix sciences, specialization marketing, in 2005 from chen University. He joined the laCN group of the JWTEC Depars ment at Thent University as a researcher affitated with the

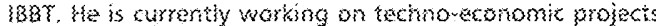
concerming newwork design, costibenetit analysis, and business modeling. He is activa within various research projects

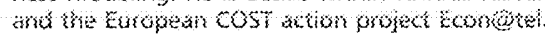

SOAi Vererugce received an M.Sc degree in computer sci ence engineening and a ph. D, degre from Ghent unversity in 2001 and $200 \%$. She is currently working with the $18 C N$ group of the INTEC Deparment at Ghent University as a researcher atfinated with the 8 B 37 . Her main research inger ests include tachnomeconomic asoects of telecom getwor pianming inckuding capiat as well as operational cos modeling.

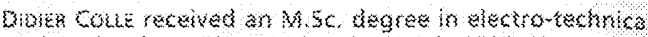

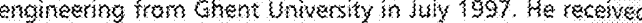

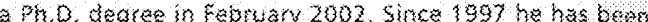

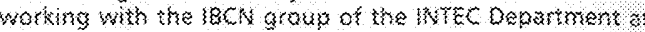

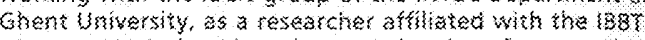

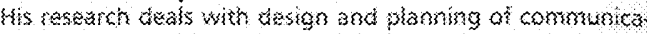

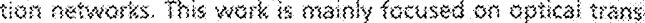

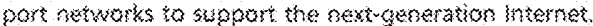

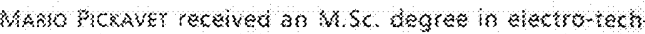

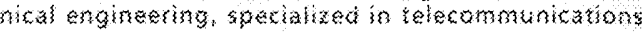

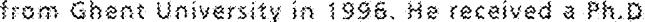
ragrae in 1999. Since 2009 he has boen a moolassot at

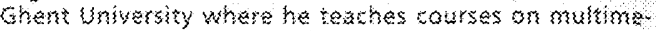
dia networks and network modeling. Wis curten

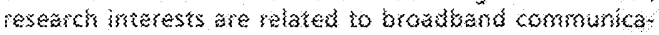

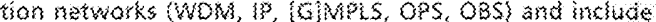
design, longrom planning, and routing of core and access networks.

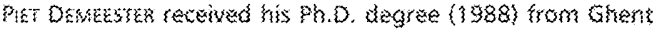
Unversity, where has kacame a prokssor in 1993. He heads a research grouo on broadband communication newworks and distribuked software: www iben inter.ugent ba kis

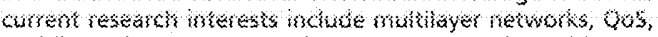
mobile ard senson retworks, access natworks, grid conputing, enercy âticient ICT, distributed solware, newwork and senica manogenent, techno-aconomics and apolica tions. He is conathor of over 700 publications in invernational journals or conference proceadings 

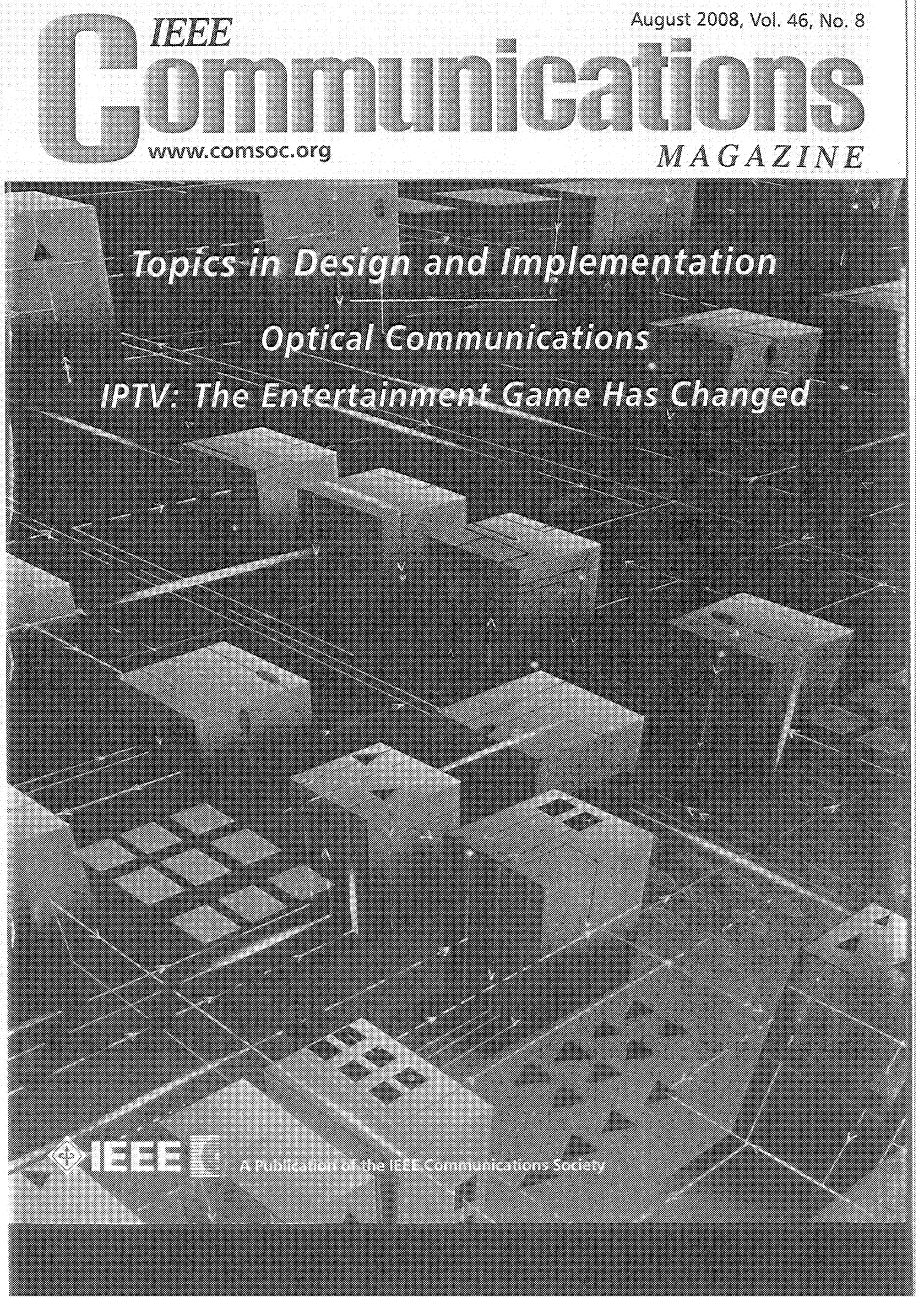